SEUNEUBOK LADA

Jurnal Ilmu-Ilmu Sejarah, Sosial, Budaya dan Kependidikan, 7 (1), 2020: 80-92

ISSN : 2356-0770

e-ISSN : 2685-2705

\title{
PENINGKATAN KINERJA GURU DALAM MENETAPKAN KRITERIA KETUNTASAN MINIMAL (KKM) BELAJAR MELALUI WORKSHOP DI SEKOLAH MENENGAH PERTAMA
}

\author{
Sulaiman \\ Kepala SMP Negeri 1 Indra Makmu, Kec. Indra Makmu, Aceh Timur \\ s61519427@gmail.com
}

\begin{abstract}
The research aims to improve teacher performance in establishing the Minimum Mastery Criteria (KKM) through the implementation of Workshop activities at SMP Negeri 1 Indra Makmu. In addition, this study also describes the readiness of teachers for the activities carried out. This research is classified as a school action research involving 10 teachers as research subjects. The study was conducted in two cycles and each cycle consisted of 4 stages: planning, implementing, observing and reflecting. The established performance indicators are: if at least $80 \%$ of teachers are classified as capable and good in the aspect of evaluating the KKM preparation, then it can be said that the actions implemented are successful. The measured aspect in assessing the success of actions is the readiness of the teacher to take part in the Workshop activities and the results of the Workshop activities. From the analysis obtained an increase in the performance of teachers in preparing KKM properly and correctly from the first cycle that is equal to $60 \%$ increased sharply in the second cycle to $90 \%$. Achievement of performance indicators is in action II. Therefore it can be concluded that through the implementation of the Workshop activities can improve the performance of teachers in preparing KKM correctly in SMP Negeri 1 Indra Makmu. It was suggested to schools that the Workshop activity could be applied as an alternative in improving teacher performance in developing KKM.
\end{abstract}

Keywords: Workshop Activities, Teacher Performance in Establishing Minimum completeness

Criteria (KKM)

\begin{abstract}
ABSTRAK
Penelitian ini dilaksanakan bertujuan untuk meningkatkan kinerja guru dalam menetapkan Kriteria Ketuntasan Minimal (KKM) melalui implementasi kegiatan Workshop di SMP Negeri 1 Indra Makmu. Selain itu, penelitian ini juga bertujuan untuk mendeskripsikan kesiapan guru terhadap kegiatan yang dilakukan. Penelitian ini tergolong penelitian tindakan sekolah dengan melibatkan 10 orang guru sebagai subjek penelitian. Penelitian dilakukan dengan dua siklus dan masing-masing siklus terdiri atas 4 tahapan, yakni: perencanaan, pelaksanaan, observasi dan refleksi. Indikator kinerja yang ditetapkan adalah: bila minimal $80 \%$ guru tergolong mampu dan baik dalam aspek penilaian terhadap penyusunan KKM, maka sudah dapat dikatakan tindakan yang diterapkan berhasil. Aspek yang diukur dalam menilai keberhasilan tindakan adalah kesiapan guru mengikuti kegiatan Workshop dan hasil pelaksanaan kegiatan Workshop. Dari analisis diperoleh bahwa terjadi peningkatan kinerja guru dalam menyusun KKM secara baik dan benar dari siklus I yaitu sebesar $60 \%$ meningkat tajam pada siklus II menjadi 90\%. Ketercapaian indikator kinerja terdapat pada tindakan II. Oleh karena itu dapat disimpulkan bahwa melalui implementasi kegiatan Workshop dapat meningkatkan kinerja guru dalam menyusun KKM secara benar di SMP Negeri 1 Indra Makmu. Dengan demikian dapat disarankan kepada sekolah yang lain bahwa kegiatan Workshop dapat diaplikasikan sebagai salah satu alternatif dalam meningkatkan kinerja guru dalam menyusun KKM.
\end{abstract}

Kata Kunci: Kegiatan Workshop, Kinerja Guru dalam Menetapkan Kriteria Ketuntasan Minimal (KKM)

Author correspondence

Email: s61519427@gmail.com

Available online at http://ejurnalunsam.id/index.php/jsnbl/index 


\section{A. PENDAHULUAN}

Seorang guru harus selalu meningkatkan kemampuan profesionalnya, pengetahuan, sikap dan keterampilannya secara terus-menerus sesuai perkembangan ilmu pengetahuan dan teknologi termasuk paradigma baru pendidikan. Menurut Syamsuddin (2005:66) ada tiga komponen utama yang saling berkaitan dan memiliki kedudukan strategis dalam kegiatan belajar mengajar. Ketiga komponen tersebut adalah kurikulum, guru, dan pembelajar (siswa). Ketiga komponen itu, guru menduduki posisi sentral sebab peranannya sangat menentukan. Dalam pembelajaran seorang guru harus mampu menerjemahkan nilai-nilai yang terdapat dalam kurikulum secara optimal. Walaupun sistem pembelajaran sekarang sudah tidak theacher center lagi, namun seorang guru tetap memegang peranan yang penting dalam membimbing siswa. Bahkan berdasarkan seorang guru harus mempunyai pengetahuan yang memadai baik di bidang akademik maupun pedagogik.

Menurut Dirjen Pendidikan Dasar dan Menengah Departeman Pendidikan Nasional (2004:2) seorang guru harus memenuhi tiga standar kompetensi, di antaranya: (1) Kompetensi Pengelolaan Pembelajaran dan Wawasan Kependidikan, (2) Kompetensi Akademik/Vokasional sesuai materi pembelajaran, Pengembangan Profesi. Ketiga kompetensi tersebut bertujuan agar guru bermutu, menjadikan pembelajaran bermutu juga, yang akhirnya meningkatkan mutu pendidikan Indonesia.

Untuk mencapai tiga kompetensi tersebut, sekolah harus melaksanakan pembinaan terhadap guru baik melalui workshop, PKG, diskusi dan supervisi edukatif. Hal itu harus dilakukan secara periodik agar kinerja dan wawasan guru bertambah sebab berdasarkan diskusi yang dilakukan guru di SMP Negeri 1 Indra Makmu, rendahnya kinerja dan wawasan guru diakibatkan (1) rendahnya kesadaran guru untuk belajar, (2) kurangnya kesempatan guru mengikuti pelatihan, baik secara regional maupun nasional, (3) kurang efektifnya PKG, (4) supervisi pendidikan yang bertujuan memperbaiki proses pembelajaran cenderung menitikberatkan pada aspek administrasi.

Berdasarkan kenyataan begitu berat dan kompleksnya tugas serta peran guru tersebut, perlu diadakan pembinaan terhadap guru secara terus menerus untuk meningkatkan kinerjanya. Kinerja guru perlu ditingkatkan agar usaha membimbing siswa untuk belajar dapat berkembang. Proses pengembangan kinerja guru terbentuk dan terjadi dalam kegiatan belajar mengajar di tempat mereka bekerja. Tindakan perbaikan yang dapat dilakukan Kepala Sekolah adalah melalui kegiatan workshop.

Anas (2012) menyebutkan bahwa workshop merupakan sebuah kegiatan yang sengaja diadakan sebagai tempat berkumpulnya orang-orang yang berasal dari latar belakang serumpun untuk memecahkan suatu permasalahan tertentu dengan jalan berdiskusi ataupun saling memberikan pendapat antar satu anggota dengan anggota lainnya. Singkatnya, workshop merupakan gabungan antara teori dan praktek. 
SEUNEUBOK LADA

Jurnal Ilmu-Ilmu Sejarah, Sosial, Budaya dan Kependidikan, 7 (1), 2020: 80-92

ISSN : 2356-0770

e-ISSN : 2685-2705

Kegiatan workshop merupakan kegiatan yang sudah sering dilakukan oleh berbagai kalangan dan meliputi berbagai bidang. Kegiatan workshop memang sangat bermanfaat, sehingga banyak pihak yang sering menyelenggarakan kegiatan tersebut. Kegiatan workshop tidak hanya dilakukan dalam dunia pendidikan, informasi yang didapat dari workshop akan membantu dalam menjalani suatu kegiatan yang tentunya sesuai dengan materi yang dibahas dari workshop tersebut. Penyusunan rencana pelaksanaan pembelajaran sangat penting, karena pengelolaan pembelajaran yang baik sangat berpengaruh terhadap penyusunan rencana pelaksanaan pembelajaran sesuai indikator. Untuk mengatasi hal tersebut perlu diupayakan pembinaan dari kepala sekolah sebagai pemimpin di sekolah tersebut.

Untuk memperbaiki kinerja dan wawasan guru dalam pembelajaran di SMP Negeri 1 Indra Makmu, sekolah melaksanakan penelitian tindakan yang berkaitan dengan permasalahan di atas. Karena keterbatasan peneliti, maka penelitian ini hanya divokuskan pada peningkatan kinerja guru melalui workshop. Adapun judul yang diangkat dalam artikel ini adalah "Peningkatan Kinerja Guru dalam Menetapkan Kriteria Ketuntasan Minimal (KKM) Belajar Melalui Workshop di Sekolah Menengah Pertama".

\section{B. TINJAUAN PUSTAKA}

\section{Kinerja Guru}

Menurut Purwanto (2005:309), kinerja guru adalah: perilaku nyata yang ditampilkan oleh guru sebagai prestasi kerja berdasarkan standar yang ditetapkan dan sesuai dengan perannya di sekolah.

Peran guru yang dimaksud adalah berkaitan dengan peran guru dalam proses pembelajaran. Guru merupakan faktor penentu yang sangat dominan dalam pendidikan pada umumnya, karena guru memegang peranan dalam proses pembelajaran, dimana proses pembelajaran merupakan inti dari proses pendidikan secara keseluruhan. Guru merupakan perencana, pelaksana sekaligus sebagai evaluator pembelajaran di kelas (Pidarta, 1990:23).

Berkaitan dengan kinerja guru dalam melaksanakan kegiatan belajar mengajar dan tugas keprofesionalan guru dalam Undang-Undang Republik Indonesia Nomor 14 Tahun 2005 pasal 20 (a) Tentang Guru dan Dosen ditegaskan bahwa guru memiliki tugas keprofesionalan dalam melaksanakan kegiatan belajar mengajar yaitu merencanakan pembelajaran, melaksanakan proses pembelajaran yang bermutu, serta menilai dan mengevaluasi hasil pembelajaran.

Dari uraian diatas penulis dapat menyimpulkan bahwa pada hakikatnya kinerja guru adalah prilaku yang dihasilkan seorang guru dalam melaksanakan tugasnya sebagai pendidik dan pengajar ketika mengajar di depan kelas, sesuai dengan kriteria tertentu seperti perencanaan program pengajaran, pelaksanaan kegiatan pembelajaran dan evaluasi hasil pembelajaran. Kinerja seseorang Guru akan nampak pada situasi 
dan kondisi kerja sehari-hari dalam aspek kegiatan menjalankan tugas dan cara/kualitas dalam melaksanakan kegiatan/tugas tersebut.

Kinerja guru dapat dilihat dan diukur berdasarkan spesifikasi/kriteria kompetensi yang harus dimiliki oleh setiap guru. Berkaitan dengan kinerja guru, wujud perilaku yang dimaksud adalah kegiatan guru dalam proses pembelajaran yaitu bagaimana kemampuan seorang guru dalam merencanakan pembelajaran, melaksanakan kegiatan pembelajaran, dan menilai hasil belajar.

\section{Kriteria Ketuntasan Minimal (KKM)}

Salah satu prinsip penilaian pada kurikulum berbasis kompetensi adalah menggunakan acuan kriteria, yakni menggunakan kriteria tertentu dalam menentukan kelulusan peserta didik. Kriteria paling rendah untuk menyatakan peserta didik mencapai ketuntasan dinamakan Kriteria Ketuntasan Minimal (KKM).

Menurut Akhmad (2008) Kriteria Ketuntasan Minimal (KKM) harus ditetapkan sebelum awal tahun ajaran dimulai. Seberapapun besarnya jumlah peserta didik yang melampaui batas ketuntasan minimal, tidak mengubah keputusan pendidik dalam menyatakan lulus dan tidak lulus pembelajaran. Acuan kriteria tidak diubah secara serta merta karena hasil empirik penilaian. Pada acuan norma, kurva normal sering digunakan untuk menentukan ketuntasan belajar peserta didik jika diperoleh hasil rata-rata kurang memuaskan. Nilai akhir sering dikonversi dari kurva normal untuk mendapatkan sejumlah peserta didik yang melebihi nilai 6,0 sesuai proporsi kurva. Acuan kriteria mengharuskan pendidik untuk melakukan tindakan yang tepat terhadap hasil penilaian, yaitu memberikan layanan remedial bagi yang belum tuntas dan atau layanan pengayaan bagi yang sudah melampaui kriteria ketuntasan minimal.

Kriteria ketuntasan minimal ditetapkan oleh satuan pendidikan berdasarkan hasil musyawarah guru mata pelajaran di satuan pendidikan atau beberapa satuan pendidikan yang memiliki karakteristik yang hampir sama. Pertimbangan pendidik atau forum MGMP secara akademis menjadi pertimbangan utama penetapan KKM.

Kriteria ketuntasan menunjukkan persentase tingkat pencapaian kompetensi sehingga dinyatakan dengan angka maksimal 100 (seratus). Angka maksimal 100 merupakan kriteria ketuntasan ideal. Target ketuntasan secara nasional diharapkan mencapai minimal 75. Satuan pendidikan dapat memulai dari kriteria ketuntasan minimal di bawah target nasional kemudian ditingkatkan secara bertahap (Darmaja: 2016).

Kriteria ketuntasan minimal menjadi acuan bersama pendidik, peserta didik, dan orang tua peserta didik. Oleh karena itu pihak-pihak yang berkepentingan terhadap penilaian di sekolah berhak untuk mengetahuinya. Satuan pendidikan perlu melakukan sosialisasi agar informasi dapat diakses dengan mudah oleh peserta didik dan atau orang tuanya. Kriteria ketuntasan minimal harus dicantumkan dalam Laporan Hasil Belajar (LHB) sebagai acuan dalam menyikapi hasil belajar peserta didik (Darmaja: 2016). 


\section{Fungsi Kriteria Ketuntasan Minimal}

Menurut Akhmad (2008) menyatakan bahwa fungsi kriteria ketuntasan minimal adalah sebagai berikut:

a. sebagai acuan bagi pendidik dalam menilai kompetensi peserta didik sesuai kompetensi dasar mata pelajaran yang diikuti. Setiap kompetensi dasardapat diketahui ketercapaiannya berdasarkan KKM yang ditetapkan. Pendidik harus memberikan respon yang tepat terhadap pencapaian kompetensi dasar dalam bentuk pemberian layanan remedial atau layananpengayaan;

b. sebagai acuan bagi peserta didik dalam menyiapkan diri mengikuti penilaianmata pelajaran. Setiap kompetensi dasar (KD) dan indikator ditetapkan KKMyang harus dicapai dan dikuasai oleh peserta didik. Peserta didik diharapkandapat mempersiapkan diri dalam mengikuti penilaian agar mencapai nilaimelebihi KKM. Apabila hal tersebut tidak bisa dicapai, peserta didik harus mengetahui KD-KD yang belum tuntas dan perlu perbaikan;

c. dapat digunakan sebagai bagian dari komponen dalam melakukan evaluasi program pembelajaran yang dilaksanakan di sekolah. Evaluasiketerlaksanaan dan hasil program kurikulum dapat dilihat dari keberhasilan pencapaian KKM sebagai tolok ukur. Oleh karena itu hasil pencapaian KD berdasarkan KKM yang ditetapkan perlu dianalisis untuk mendapatkan informasi tentang peta KDKD tiap mata pelajaran yang mudah atau sulit, dan cara perbaikan dalam proses pembelajaran maupun pemenuhan sarana prasarana belajar di sekolah;

d. merupakan kontrak pedagogik antara pendidik dengan peserta didik dan antara satuan pendidikan dengan masyarakat. Keberhasilan pencapaian KKM merupakan upaya yang harus dilakukan bersama antara pendidik, peserta didik, pimpinan satuan pendidikan, dan orang tua. Pendidik melakukan upaya pencapaian KKM dengan memaksimalkan proses pembelajaran dan penilaian. Peserta didik melakukan upaya pencapaian KKM dengan proaktif mengikuti kegiatan pembelajaran serta mengerjakan tugas-tugas yang telah didesain pendidik. Orang tua dapat membantu dengan memberikan motivasi dan dukungan penuh bagi putra-putrinya dalam mengikuti pembelajaran. Sedangkan pimpinan satuan pendidikan berupaya memaksimalkan pemenuhan kebutuhan untuk mendukung terlaksananya proses pembelajaran dan penilaian di sekolah;

e. merupakan target satuan pendidikan dalam pencapaian kompetensi tiapmata pelajaran. Satuan pendidikan harus berupaya semaksimal mungkin untuk melampaui KKM yang ditetapkan. Keberhasilan pencapaian KKM merupakan salah satu tolok ukur kinerja satuan pendidikan dalam menyelenggarakan program pendidikan. Satuan pendidikan dengan KKM yang tinggi dan dilaksanakan secara bertanggung jawab dapat menjadi tolok ukur kualitas mutu pendidikan bagi masyarakat.

\section{Prinsip Penetapan KKM}

Penetapan Kriteria Ketuntasan Minimal perlu mempertimbangkan beberapa ketentuan, ha ini sebagaimana diuraikan Akhmad (2008) sebagai berikut:

a. Penetapan KKM merupakan kegiatan pengambilan keputusan yang dapat dilakukan melalui metode kualitatif dan atau kuantitatif. Metode kualitatif dapat dilakukan melalui professional judgement oleh pendidik dengan mempertimbangkan kemampuan akademik dan pengalaman pendidik mengajar 
mata pelajaran di sekolahnya. Sedangkan metode kuantitatif dilakukan dengan rentang angka yang disepakati sesuai dengan penetapan kriteria yang ditentukan;

b. Penetapan nilai kriteria ketuntasan minimal dilakukan melalui analisis ketuntasan belajar minimal pada setiap indikator dengan memperhatikan kompleksitas, daya dukung, dan intake peserta didik untuk mencapai ketuntasan kompetensi dasar dan standar kompetensi;

c. Kriteria ketuntasan minimal setiap Kompetensi Dasar (KD) merupakan rata-rata dari indikator yang terdapat dalam Kompetensi Dasar tersebut. Peserta didik dinyatakan telah mencapai ketuntasan belajar untuk KD tertentu apabila yang bersangkutan telah mencapai ketuntasan belajar minimal yang telah ditetapkan untuk seluruh indikator pada KD tersebut;

d. Kriteria ketuntasan minimal setiap Standar Kompetensi (SK) merupakan ratarata KKM Kompetensi Dasar (KD) yang terdapat dalam SK tersebut;

e. Kriteria ketuntasan minimal mata pelajaran merupakan rata-rata dari semua KKM-SK yang terdapat dalam satu semester atau satu tahun pembelajaran, dan dicantumkan dalam Laporan Hasil Belajar (LHB/Rapor)peserta didik;

f. Indikator merupakan acuan/rujukan bagi pendidik untuk membuat soal-soal ulangan, baik Ulangan Harian (UH), Ulangan Tengah Semester (UTS) maupun Ulangan Akhir Semester (UAS). Soal ulangan ataupun tugas-tugas harus mampu mencerminkan/menampilkan pencapaian indikator yang diujikan. Dengan demikian pendidik tidak perlu melakukan pembobotan seluruh hasil ulangan, karena semuanya memiliki hasil yang setara;

g. Pada setiap indikator atau kompetensi dasar dimungkinkan adanya perbedaan nilai ketuntasan minimal.

\section{Langkah-Langkah Penetapan KKM}

Penetapan KKM dilakukan oleh guru atau kelompok guru mata pelajaran. Langkah penetapan KKM menurut Akhmad (2008) adalah sebagai berikut:

a. Guru atau kelompok guru menetapkan KKM mata pelajaran dengan mempertimbangkan tiga aspek kriteria, yaitu kompleksitas. Hasil penetapan KKM indikator berlanjut pada KD, SK hingga KKM mata pelajaran;

b. Hasil penetapan KKM oleh guru atau kelompok guru mata pelajaran disahkan oleh kepala sekolah untuk dijadikan patokan guru dalam melakukan penilaian;

c. KKM yang ditetapkan disosialisaikan kepada pihak-pihak yang berkepentingan, yaitu peserta didik, orang tua, dan dinas pendidikan;

d. KKM dicantumkan dalam LHB pada saat hasil penilaian dilaporkan kepada orang tua/wali peserta didik.

\section{Kajian Workshop}

a. Konsep Workshop

Kata workshop juga bisa diartikan sebagai tempat berkumpulnya sejumlah orang yang memiliki latar belakang yang sama, yang berdiskusi tentang suatu permasalahan dengan cara memberi gagasan/pendapat tentang masalah tersebut yang dilakukan untuk saling bertukar ilmu pengetahuan dan pengalaman di antara para peserta yang memiliki profesi atau keahlian yang sama. Workshop berguna untuk 
menambah ilmu pengetahuan atau mendapatkan solusi terbaik atas permasalahan tertentu (Anas: 2012).

Dalam dunia pendidikan workshop adalah suatu cara belajar sesuatu (a way learning) dengan menggunakan sharing of ideas, prosedure give and take atau "suatu sistem kerja yang selaras dengan jiwa gotong-royong" (Sora: 2016). Pengertian workshop dalam dunia pendidikan adalah proses kegiatan belajar secara kelompok maupun perorangan dimana tenaga pendidik dapat melakukan sharing suatu problem atau masalah yang dihadapi melalui percakapan dan tanya jawab. Dalam kegiatan workshop, para peserta juga dihadapkan dengan praktek langsung untuk lebih mengenal suatu masalah. Dalam sebuah workshop akan berkumpul sekelompok orang yang memiliki minat/perhatian dan keahlian yang sama di dalam bidang tertentu, di mana mereka akan berkumpul di bawah kepemimpinan beberapa orang yang sudah ahli untuk menggali satu atau beberapa aspek khusus suatu pembahasan masalah (Hilda: 2016).

Dalam pelaksanaannya, sebuah workshop bisa saja dibagi menjadi beberapa kelompok yang dibentuk dengan berbagai macam tujuan, seperti: melihat demonstrasi-demonstrasi, mendengarkan ceramah, mendiskusikan berbagai aspek topik, mempelajari, mengerjakan, mempraktekkan, serta mengevaluasi topik tersebut setelahnya. Pada umumnya sebuah workshop akan terdiri dari seorang pimpinan workshop, anggota, dan para nara sumber informasi.

\section{b. Langkah-Langkah Pelaksanaan Workshop}

Berikut ini Sora (2016) memaparkan langkah-langkah yang perlu dilakukan dalam melaksankan sebuah workshop antara lain:

1) Perencanaan

Pertama-tama, harus ditentukan tujuan, apakah hanya memberikan informasi atau bimbingan tentang topik tertentu, atau untuk mendapatkan solusi atas permasalahan tertentu. Setelah itu, buatlah rancangan presentasi untuk workshop, serta perkiraan alokasi waktu yang dibutuhkan.

2) Menyiapkan Bahan Pendukung Workshop

Siapkan bahan pendukung workshop seperti naskah tulisan, atau data penting yang nantinya akan dibagikan pada para peserta. Kita juga bisa menggunakan alat peraga visual, misalnya dengan menunjukkan film atau video tertentu agar presentasi terlihat menarik bagi peserta workshop.

3) Mendorong Partisipasi dari Peserta Workshop

Aturlah ruangan sedemikian rupa agar peserta bisa nyaman saat berdiskusi. Siapkan juga papan tulis untuk mencatat ide kreatif yang nantinya akan diajukan oleh para peserta. Jangan lupa untuk memasukkan kegiatan interaktif seperti games dalam kegiatan workshop. Hal ini akan meningkatkan tingkat partisipasi dari peserta workshop. Sertakan pula sesi tanya jawab agar peserta bisa mengajukan pertanyaan.

4) Selalu Siapkan Rencana Cadangan

Perlu mempertimbangkan beberapa hal penting yang bisa saja timbul di luar perkiraan, misalnya jumlah peserta yang hadir hanya sedikit, laptop rusak, 
SEUNEUBOK LADA

Jurnal Ilmu-Ilmu Sejarah, Sosial, Budaya dan Kependidikan, 7 (1), 2020: 80-92

ISSN : 2356-0770

e-ISSN : 2685-2705

dan lain sebagainya. Karena itulah, jika memungkinkan, ada baiknya kamu membuat rencana cadangan untuk mengantisipasinya. Misalnya saja dengan menyiapkan laptop ekstra, dan lain sebagainya.

\section{PEMBAHASAN}

Berdasarkan hasil penelitian yang telah dilakukan bahwa implementasi Workshop dapat meningkatkan kompetensi guru dalam menyusun instrumen penilaian hasil belajar di SMP Negeri 1 Indra Makmu, Kec. Indra Makmu, Kab. Aceh Timur. Hal tersebut dapat dianalisis dan dibahas sebagai berikut:

\section{Pembahasan Hasil Kegiatan Kondisi Awal}

Sebelum dilaksanakan penelitian, gambaran kondisi awal terkait kinerja para guru di SMP Negeri 1 Indra Makmu, Kec. Indra Makmu, Kab. Aceh Timur dalam menyusun menetapkan Kriteria Ketuntasan Minimal (KKM) sangatlah rendah. Guru-guru masih kesulitan di dalam menyusun menetapkan Kriteria Ketuntasan Minimal (KKM) yang baik dan benar. Kriteria Ketuntasan Minimal (KKM) harus ditetapkan sebelum awal tahun ajaran dimulai. Seberapapun besarnya jumlah peserta didik yang melampaui batas ketuntasan minimal, tidak mengubah keputusan pendidik dalam menyatakan lulus dan tidak lulus pembelajaran. Keberhasilan pencapaian KKM merupakan salah satu tolok ukur kinerja satuan pendidikan dalam menyelenggarakan program pendidikan.

Hal ini tentu saja sangat berpengaruh pada efektifitas proses pembelajaran dan dapat menyebabkan mutu pendidikan menjadi rendah. Dari 10 orang guru hanya 1 orang (10\%) guru yang mampu menyusun Kriteria Ketuntasan Minimal (KKM) dan sudah menerapkannya. Sedangkan selebihnya sebanyak 9 orang guru (90\%) belum mampu menyusun Kriteria Ketuntasan Minimal (KKM) yang baik dan benar serta belum bisa menerapkan dalam proses pembelajaran. Selebihnya masih belum memahami bagaimana cara menetapkan Kriteria Ketuntasan Minimal (KKM) sesuai prosedur yang harus dipahami oleh seorang guru.

\section{Pembahasan Hasil Kegiatan Siklus I}

Gambaran hasil tindakan pada pelaksanaan siklus I menunjukkan adanya sedikit peningkatan kompetensi guru dalam menyusun Kriteria Ketuntasan Minimal (KKM) dibandingkan dengan kondisi awal walaupun belum mencapai hasil sesuai dengan yang diharapkan. Pada siklus I, secara garis besar penyusunan Kriteria Ketuntasan Minimal (KKM) melalui implementasi Workshop sudah dilaksanakan dengan baik, tetapi daya serap guru terhadap materi yang disampaikan narasumber belum semuanya terakumulasikan dengan baik, karena implementasi Workshop tersebut masih dirasakan baru oleh guru.

Selama kegiatan Workshop berlangsung, kegiatan peserta juga diobservasi mengenai kesiapan mental dan fisik guru, kesiapan bahan-bahan yang dibawa guru pada waktu kegiatan Workshop, kesiapan laptop, pemahaman terhadap substansi KKM, dan respon positif guru. Berdasarkan data hasil penelitian, diketahui bahwa kesiapan guru dalam mengikuti kegiatan Workshop diperoleh data dari segi aspek 
kesiapan mental terdapat 6 guru (60\%), kesiapan bahan terdapat 5 guru (50\%), kesiapan laptop hanya 4 orang guru (40\%), pemahaman terhadap substansi KKM hanya 5 orang guru (50\%), dan yang merespon kegiatan Workshop secara positif terdapat 7 orang guru $(70 \%)$. Secara umum hasil yang dicapai sudah meningkat namun masih jauh dari target yang diharapkan.

Pada prinsipnya pihak peneliti menyadari bahwa, untuk meningkatkan pemahaman guru dalam menyusun Kriteria Ketuntasan Minimal (KKM) tidak semudah yang dibayangkan, intinya bahwa guru peserta kegiatan telah memahami substansi rancangan Kriteria Ketuntasan Minimal (KKM) meski dalam taraf sederhana. Kekurangan yang ada akan diupayakan untuk diminimalisir, oleh karena itu berdasarkan hasil refleksi tersebut perlu diupayakan perbaikan-perbaikan kekurangan-kekurangan tersebut pada siklus kedua. Berdasarkan hasil yang dicapai pada pelaksanaan tindakan siklus I tersebut, peneliti merasa belum puas atas pencapaian tersebut. Oleh karena itu peneliti melanjutkan pada siklus II dengan terlebih dahulu melakukan perbaikan atas kelemahan yang terjadi pada siklus sebelumnya.

\section{Pembahasan Hasil Kegiatan Siklus II}

Pada pelaksanaan tindakan siklus II terjadi peningkatan yang cukup signifikan dibandingkan dengan hasil tindakan siklus I. Hal ini disebakan peneliti secara terus menerus melakukan bimbingan dan arahan kepada para guru agar mampu meningkatkan kompetensinya dalam menyusun instrumen penilaian hasil belajar secara baik sehingga proses pembelajaran menjadi lebih efektif yang pada akhirnya akan meningkatkan mutu pendidikan.

Berdasarkan hasil pelaksanaan kegiatan yang telah dilakukan pada siklus kedua, diperoleh data bahwa pemahaman peserta telah terjadi peningkatan. Gambaran peningkatan kompetensi guru dalam kegiatan Workshop pada siklus II dapat dilihat bahwa dari 10 orang guru, sejumlah 9 orang (90\%) guru yang mampu menyusun KKM dan sudah memahami substansinya. Sedangkan selebihnya sebanyak 1 orang guru (10\%) belum mampu menyusun KKM yang baik dan benar serta belum bisa menerapkan dalam proses pembelajaran.

Pelaksanaan Workshop peningkatan kinerja guru dalam menyusun Kriteria Ketuntasan Minimal (KKM) pada siklus II ini juga menilai kesiapan guru dalam mengikuti workshop. Berdasarkan hasil rekapitulasi data mengenai kesiapan guru SMP Negeri 1 Indra Makmu dalam mengikuti kegiatan Workshop siklus II diketahui bahwa kesiapan mental dan fisik guru, kesiapan bahan-bahan yang dibawa guru pada waktu kegiatan Workshop, kesiapan laptop, pemahaman terhadap substansi KKM, dan respon positif guru. Berdasarkan data hasil penelitian, diketahui bahwa kesiapan guru SMP Negeri 1 Indra Makmu dalam mengikuti kegiatan Workshop diperoleh data dari segi aspek kesiapan mental terdapat 8 guru (80\%), kesiapan bahan terdapat 9 orang guru (90\%), kesiapan laptop terdapat 7 orang guru (70\%), pemahaman terhadap substansi KKM sudah mencapai 8 orang guru $(80 \%)$, dan yang merespon 
SEUNEUBOK LADA

Jurnal Ilmu-Ilmu Sejarah, Sosial, Budaya dan Kependidikan, 7 (1), 2020: 80-92

ISSN : 2356-0770

e-ISSN : 2685-2705

kegiatan Workshop secara baik sudah mencapai 10 orang guru (100\%). Secara umum hasil yang dicapai sudah meningkat dan sesuai dengan target yang diharapkan.

Berdasarkan hasil analisis instrumen monitoring dapat disimpulkan bahwa pelaksanaan Workshop penyusunan KKM pada siklus kedua berhasil dengan baik. Hal ini dibuktikan dengan adanya peningkatan yang signifikan terhadap kemampuan guru dalam menyerap materi kegiatan yang disampaikan narasumber pada siklus II diperoleh persentase nilai rata-rata untuk penilaian peserta terhadap kualitas pelaksanaan Workshop, Harapan peneliti, hendaknya peserta dapat mengaplikasikannya dalam proses pembelajaran secara berkelanjutan.

Dalam penyusunan persiapan kegiatan Workshop menurut pengamatan peneliti, pada siklus II guru sudah lebih baik dari pada siklus I, begitu juga dengan peserta jauh lebih meningkat dalam memahami rancangan penyusunan KKM. Dengan demikian dapat disimpulkan bahwa pelaksanaan program Workshop tercapai seperti yang diharapkan. Hal ini tidak terlepas dari kerja sama yang baik antara peneliti, pengawas pembina, guru, staf tata usaha, dan narasumber.

Kompetensi guru SMP Negeri 1 Indra Makmu yang telah mengalami peningkatan karena diadakannya kegiatan Workshop ini, perlu dilakukan pembinaan berkelanjutan dan melakukan supervisi kepada guru baik dari pihak kepala sekolah maupun pihak pengawas sekolah secara optimal sehingga para guru tetap konsisten dalam memahami substansi rancangan KKM. Hal ini juga sangat bermanfaat bagi kualitas guru dan meningkatkan kesuksesan proses belajar mengajar. Dengan demikian peneliti menetapkan bahwa Penelitian Tindakan Sekolah ini dirasa telah memadai hanya pada siklus II dan tidak melanjutkan ke siklus berikutnya karena nilai rata-rata telah mencapai indikator keberhasilan penelitian sebagaimana yang diharapkan.

Agar lebih jelas gambaran peningkatan kinerja guru dalam merancang penyusunan KKM dari kondisi awal, siklus I dan siklus II, dapat dilihat dan diperhatikan pada rekapitulasi tabel dan grafik berikut:

Tabel 1. Rekapitulasi perbandingan Kinerja Guru dalam Menyusun KKM setiap siklus

\begin{tabular}{|c|l|c|c|c|c|c|c|}
\hline \multirow{2}{*}{ No } & \multirow{2}{*}{ Keterangan } & \multicolumn{2}{|c|}{ Kondisi Awal } & \multicolumn{2}{c|}{ Siklus I } & \multicolumn{2}{c|}{ Siklus II } \\
\cline { 3 - 8 } & $\begin{array}{c}\text { Jumlah } \\
\text { Guru }\end{array}$ & Persentase & $\begin{array}{c}\text { Jumlah } \\
\text { Guru }\end{array}$ & Persentase & $\begin{array}{c}\text { Jumlah } \\
\text { Guru }\end{array}$ & Persentase \\
\hline 1. & Mampu Menyusun KKM & 1 & $10 \%$ & 6 & $60 \%$ & 9 & $90 \%$ \\
\hline 2. & $\begin{array}{l}\text { Belum Mampu } \\
\text { Menyusun KKM }\end{array}$ & 9 & $90 \%$ & 4 & $40 \%$ & 1 & $10 \%$ \\
\hline \multicolumn{2}{|c|}{ Jumlah } & 10 & 10 & 10 & $100 \%$ & 10 & $100 \%$ \\
\hline
\end{tabular}

Data pada tabel di atas jika di gambarkan dalam grafik maka akan tampak seperti berikut; 
SEUNEUBOK LADA

Jurnal Ilmu-Ilmu Sejarah, Sosial, Budaya dan Kependidikan, 7 (1), 2020: 80-92

ISSN : 2356-0770

e-ISSN : 2685-2705

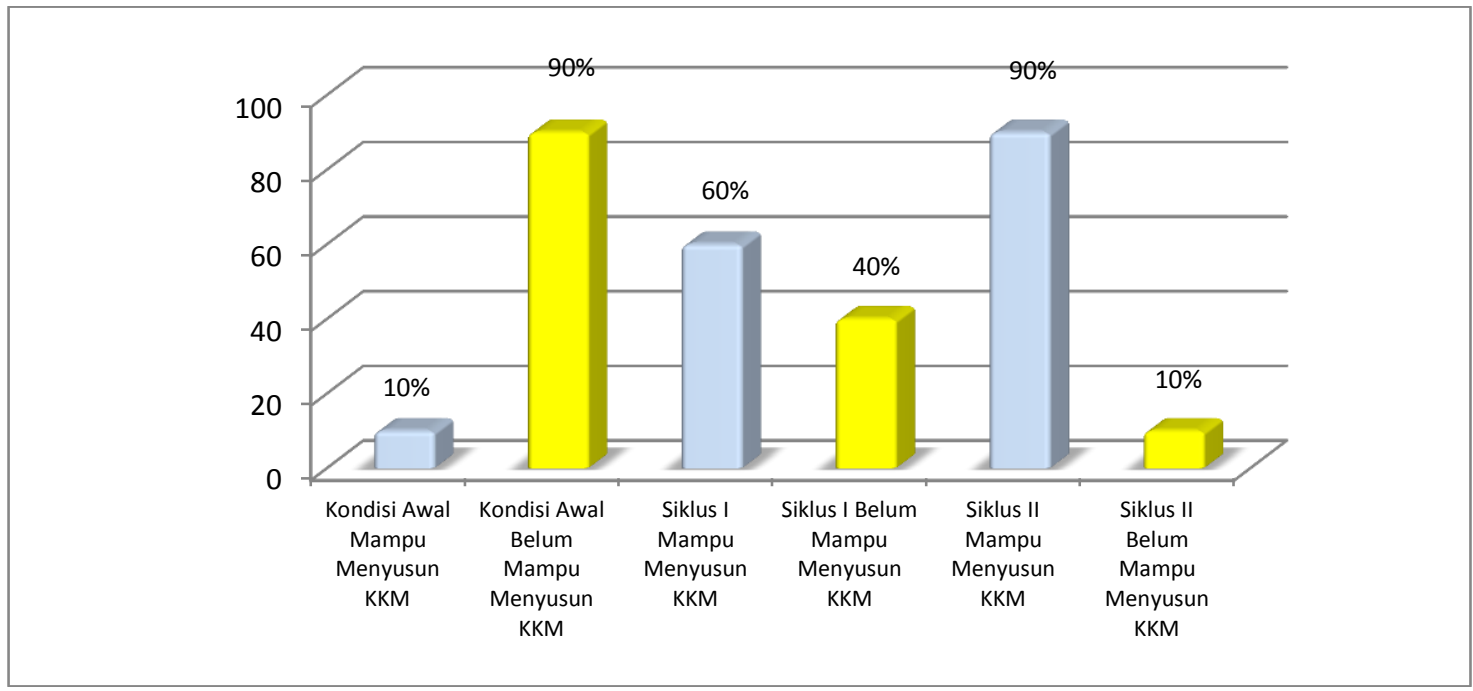

Gambar 1. Grafik Perbandingan Kinerja Guru dalam Menyusun KKM Setiap Siklus

Selama kegiatan workshop berlangsung, juga dilakukan penilaian mengenai kesiapan mental, kesiapan bahan, kesiapan laptop, pemahaman terhadap substansi KKM, dan yang merespon kegiatan Workshop secara baik. Adapun hasil observasi sebagai berikut;

Tabel 2. Rekapitulasi Perbandingan Kesiapan Guru dalam Mengikuti Workshop Siklus I dan II

\begin{tabular}{|c|c|c|c|c|c|c|c|c|c|c|c|}
\hline \multirow{2}{*}{ No } & \multirow{2}{*}{$\begin{array}{c}\text { Aspek yang } \\
\text { diamati }\end{array}$} & \multicolumn{4}{|c|}{ Siklus I } & \multirow{2}{*}{ Kriteria } & \multicolumn{4}{|c|}{ Siklus II } & \multirow{2}{*}{ Kriteria } \\
\hline & & $\mathrm{T}$ & Persentase & $\mathrm{R}$ & Persentase & & $\mathrm{T}$ & Persentase & $\mathrm{R}$ & Persentase & \\
\hline 2 & Kesiapan Bahan & 5 & $50 \%$ & 5 & $50 \%$ & Kurang & 9 & $90 \%$ & 1 & $10 \%$ & $\begin{array}{l}\text { Amat } \\
\text { Baik }\end{array}$ \\
\hline 3 & Kesiapan Laptop & 4 & $40 \%$ & 6 & $60 \%$ & Kurang & 7 & $70 \%$ & 3 & $30 \%$ & Baik \\
\hline 5 & Respon Positif & 7 & $70 \%$ & 3 & $30 \%$ & Baik & 10 & $100 \%$ & - & $0 \%$ & $\begin{array}{l}\text { Amat } \\
\text { Baik }\end{array}$ \\
\hline
\end{tabular}

Keterangan:

$\mathrm{T}=$ Tinggi

$\mathrm{R}=$ Rendah

Rentang Skor

$86 \%-100 \%=$ Amat Baik $(\mathrm{A})$

$71 \%-85 \%=$ Baik $(\mathrm{B})$

$56 \%-70 \%=$ Cukup $(\mathrm{C})$

$41 \%-55 \%=$ Kurang (D)

$01 \%-40 \%=$ Buruk $(\mathrm{E})$

Data pada tabel di atas jika di gambarkan dalam grafik maka akan tampak seperti berikut; 
SEUNEUBOK LADA

Jurnal Ilmu-Ilmu Sejarah, Sosial, Budaya dan Kependidikan, 7 (1), 2020: 80-92

ISSN : 2356-0770

e-ISSN : 2685-2705

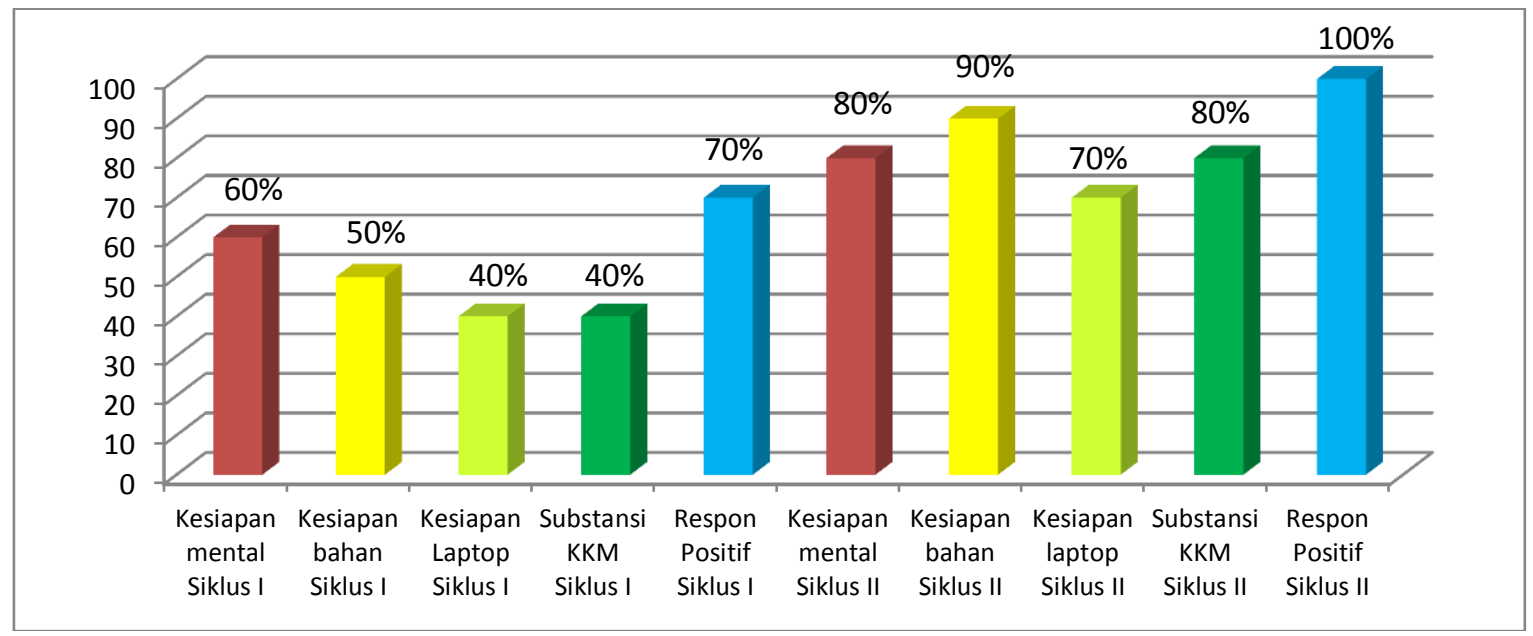

Gambar 2. Grafik Perbandingan Perbandingan Kesiapan Guru dalam Mengikuti Workshop Siklus I dan II

Dari paparan data melalui tabel dan grafik, diketahui bahwa secara umum hasil yang dicapai sudah meningkat setiap siklusnya, baik dari segi kinerja guru dalam menyusun KKM maupun dari segi kesiapan guru dalam mengikuti workshop dan sesuai dengan target yang diharapkan. Dengan demikian peneliti menetapkan bahwa Penelitian Tindakan Sekolah ini dirasa telah memadai hanya pada siklus II dan tidak melanjutkan ke siklus berikutnya karena nilai rata-rata telah mencapai indikator keberhasilan penelitian sebagaimana yang diharapkan.

\section{KESIMPULAN}

Berdasarkan hasil penelitian dan tujuan yang diharapkan dalam penelitian ini, maka ditarik kesimpulan sebagai berikut.

1. Terjadi peningkatan terhadap kinerja guru dalam menyusun KKM dalam kegiatan workshop ditiap siklusnya dan memberikan hasil yang bermanfaat bagi guru sehingga dapat berpengaruh positif terhadap kualitas pembelajaran di SMP Negeri 1 Indra Makmu.

2. Secara keseluruhan implementasi kegiatan workshop di SMP Negeri 1 Indra Makmu menunjukkan peningkatan secara klasikal. Pada kondisi awal jumlah guru yang mampu menyusun KKM secara mandiri dan sudah menerapkannya hanya 1 orang (10\%), setelah dilakukan tindakan maka pada siklus I jumlah guru yang mampu menyusun KKM secara mandiri meningkat menjadi 6 orang (60\%) dan pada siklus II terjadi peningkatan yang cukup signifikan yaitu jumlah guru yang mampu menyusun KKM secara mandiri sebanyak 9 orang (90\%).

3. Adapun kesiapan guru SMP Negeri 1 Indra Makmu dalam mengikuti kegiatan workshop siklus I, diperoleh data dari segi aspek kesiapan mental terdapat 6 guru (60\%), kesiapan bahan terdapat 5 guru (50\%), kesiapan laptop hanya 4 orang guru $(40 \%)$, pemahaman terhadap substansi KKM hanya 5 orang guru $(50 \%)$, dan yang merespon kegiatan Workshop secara positif terdapat 7 orang guru $(70 \%)$. Secara umum hasil yang dicapai sudah meningkat namun masih jauh dari target yang diharapkan. Sedangkan pada siklus II, diperoleh data dari 
segi aspek kesiapan mental terdapat 8 guru (80\%), kesiapan bahan terdapat 9 orang guru (90\%), kesiapan laptop terdapat 7 orang guru (70\%), pemahaman terhadap substansi KKM sudah mencapai 8 orang guru $(80 \%)$, dan yang merespon kegiatan Workshop secara baik sudah mencapai 10 orang guru $(100 \%)$.

\section{DAFTAR PUSTAKA}

Akhmad. 2008. Pengertian, Fungsi, dan Mekanisme Penetapan KKM. https://akhmadsudrajat.wordpress.com/2008/08/15/pengertian-fungsi-danmekanisme-penetapan-kriteria-ketuntasan-minimal-kkm/. Diunduh pada tanggal 17 Januari 2019.

Anas, A. 2012. Workshop dan Jenisnya. http: // anasaff. blogspot. co. id / 2012/ 08/workshop-dan-jenisnya.html. Diunduh tanggal 2 Febuari 2019.

Darmaja, G. 2016. Pengertian Kriteria Ketuntasan Minimal. https://disdikpora.bulelengkab.go.id/artikel/pengertian-kriteria-ketuntasanminimal-43. Diunduh pada tanggal 17 Januari 2019.

Hilda, T. 2016. Workshop; Pengertian, Ciri, Tata Pelaksanaan, Jenis, Kelebihan, Kekurangan, dan Cara Mempersiapkannya. https: // www. kata.co.id/ pengertian/workshop/1571. Diunduh tanggal 2 Febuari 2019.

Pidarta, M. 1990. Perencanaan Pendidikan Partisipatori. Jakarta: Rineka Cipta.

Purwanto, N. 2005. Administrasi dan Supervisi Pendidikan. Bandung: PT. Remaja Rosda Karya.

Sora, N. 2016. Pembahasan Pengertian Workshop dan Contohnya. http://www. pengertianku. net/2017/09/ pengertian- workshop - dan - contohnya. html. Diunduh tanggal 17 Januari 2019.

Undang-Undang Republik Indonesia Nomor 14 Tahun 2005 pasal 20. 